\title{
Evaluation of early left-ventricular remodeling six months after heart transplantation
}

\author{
Daniel Lovrić*, Davor Miličić, Jure Samardžić, Vlatka Rešković Lukšić, Željko Baričević, \\ Maja Čikeš, Boško Skorić, Ivan Škorak, Jana Ljubas Maček, Irena Ivanac Vranešić, \\ Jadranka Šeparović Hanževački \\ University Hospital Center Zagreb, Zagreb, Croatia
}

\begin{abstract}
Background: At the time of transplantation, donor heart is susceptible to a myriad of factors including both ischaemia and acute immune response that could result in early and reversible thickening of the left ventricular wall. It is vital to differentiate that early thickening of the left ventricular (LV) wall from late hypertrophy that is due to denervation, immune response and myoproliferation. Therefore, we compared early postoperative echocardiography findings with the same measurements performed six months after transplantation.
\end{abstract}

Methods: 22 patients after heart transplantation were assessed by echocardiography during postoperative hospital stay and at the follow-up visit at six months using standard M-mode, 2D and Doppler measurements. Baseline measurements of end-diastolic interventricular septum (IVSd), LV posterior wall thickness (LVPWd) and LV cavity dimension (LVIDd) were assessed using M-mode echocardiography. LV mass was estimated in calculation using cubed formula, volumes and systolic function were assessed using Simpson method. Diastolic function was assessed through analysis of transmitral and pulmonary venous Doppler flow and tissue Doppler analysis of movement of mitral anulus and classified according to grades of disfunction. Student T-test was used for statistical analysis.

Results: IVSd decreased significantly from $11.8 \mathrm{~mm} \pm 2$ to $9.3 \mathrm{~mm} \pm 2(P<0.01)$ while LVPWd thickness decreased from $11.7 \mathrm{~mm} \pm 3$ to $9,3 \mathrm{~mm} \pm 3(P<0.01)$. LVIDd significantly increased in the follow up from average $44.9 \mathrm{~mm}$ to $47.7 \mathrm{~mm}$ $(\mathrm{P}<0.02)$ while LV mass decreased significantly from $197.1 \mathrm{~g}$ to $156.4 \mathrm{~g}(\mathrm{P}<0.01)$ with no statistically significant change in $L V$ volumes $(P=0.49$ for change in end-diastolic volumes, $\mathrm{P}=0.37$ for change in end-systolic volumes). There was a significant improvement in diastolic function $(P<0.05)$, and no change in systolic function ( $\mathrm{P}=0.74)$.

Conclusions: Statistically significant remodeling of implanted hearts 6 months after heart transplantation was found in all 22 patients. Thickness of interventricular septum and posterior wall in almost all patients immediately after heart transplantation was on the upper limit of normal or showing mild hypertrophy according to measurements, but after six months all the values decreased and normalized. Also, the patients that were showing diastolic dysfunction showed normal inflow patterns after six months. We presume this is the consequence of postoperative interstitial oedema that could result both from prolonged ischemia during transportation as well as early immune response of the host, but which appears to be a normal finding early after heart transplantation.

KEYWORDS: cardiac transplation, cardiac hypertrophy, myocardial remodeling, acute immune response.

\section{Received: $20^{\text {th }}$ Mar 2013}

*Address for correspondence: Klinički bolnički centar Zagreb, Kišpatićeva 12 , HR-10000 Zagreb, Croatia.

Phone: +385-1-2388-888

E-mail: daniel@dlovric.net

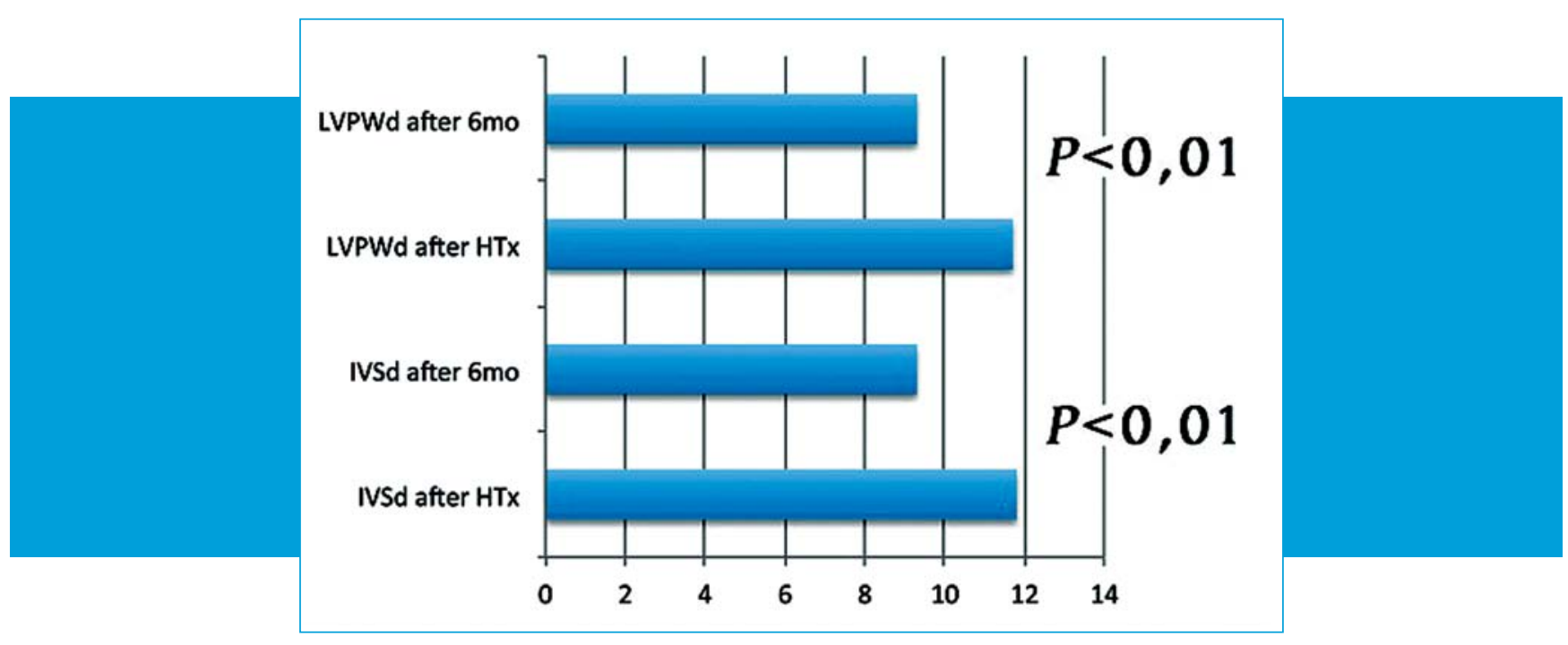



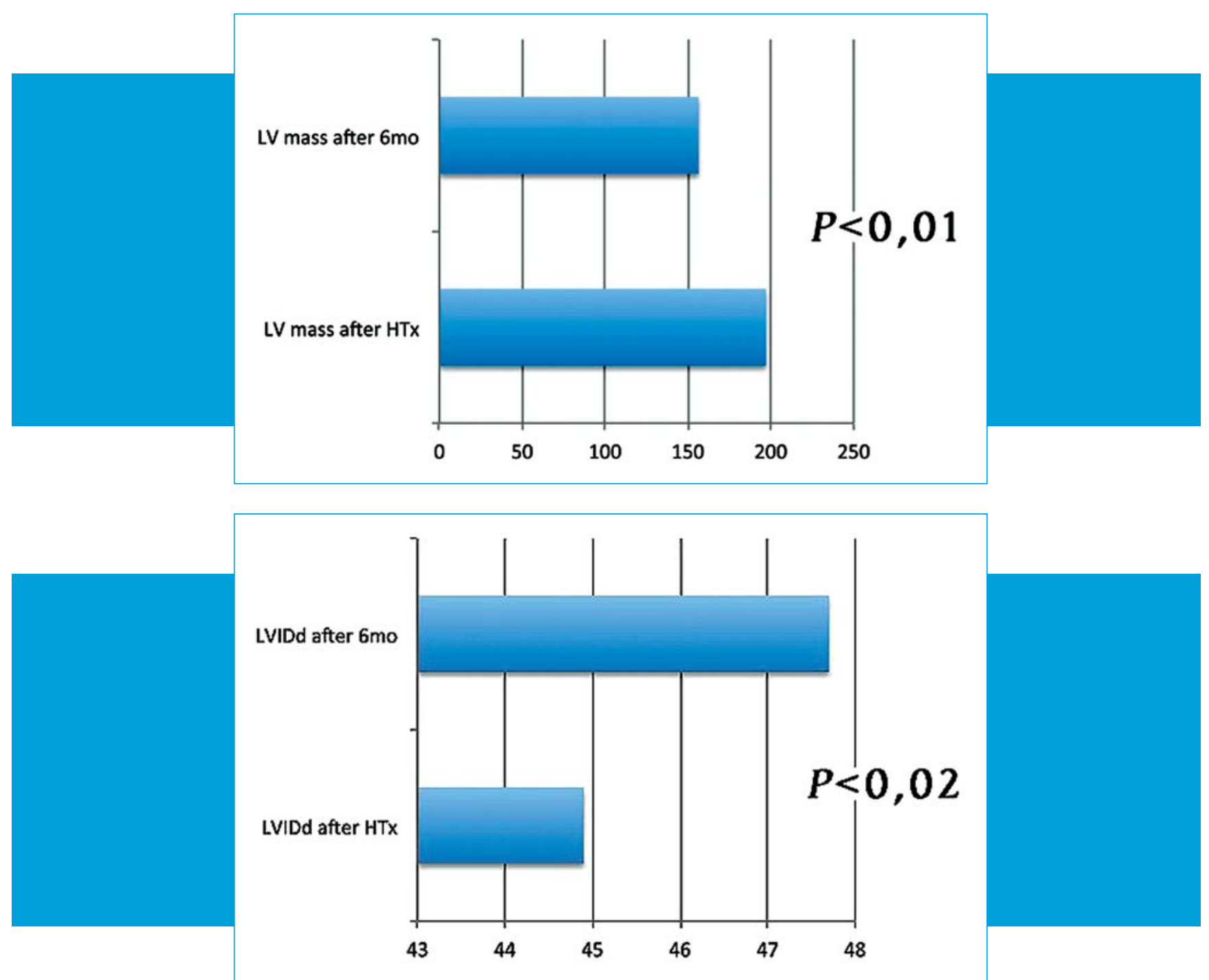

Figures 1-3. Changes in echocardiographic left ventricular parameters in 6 months.

\section{Literature}

1. Lunze FI, Colan SD, Gauvreau K, Chen MH, Perez-Atayde AR, Blume ED, et al. Cardiac allograft function during the first year after transplantation in rejection-free children and young adults. Circ Cardiovasc Imaging. 2012;5(6):756-64.

2. Pereira NL, Zile MR, Harley RA, Van Bakel AB. Myocardial mechanisms causing heart failure early after cardiac transplantation. Transplant Proc. 2006;38(9):2999-3003.

3. Slater JP, Amirhamzeh MM, Yano OJ, Shah AS, Starr JP, Kaplon RJ, et al. Discriminating between preservation and reperfusion injury in human cardiac allografts using heart weight and left ventricular mass. Circulation. 1995;92(9 Suppl):II223-7.

4. Hosenpud JD, Norman DJ, Cobanoglu MA, Floten HS, Conner RM, Starr A. Serial echocardiographic findings early after heart transplantation: evidence for reversible right ventricular dysfunction and myocardial edema. J Heart Transplant. 1987;6(6):343-7.

5. Haddad F, Khazanie P, Deuse T, Weisshaar D, Zhou J, Nam CW, et al. Clinical and functional correlates of early microvascular dysfunction after heart transplantation. Circ Heart Fail. 2012;5(6):759-68. 